\title{
Internetifolkloor globaalse pandeemia ajal: COVID-19 Valgevene veebihuumoris
}

\author{
Anastasiya Fiadotava \\ Eesti Kirjandusmuuseumi folkloristika osakonna nooremteadur \\ anastasiya.fiadotava@folklore.ee
}

Teesid: COVID-19 pandeemia esimestel kuudel (veebruarist juulini 2020) kogusin Valgevene sotsiaalmeediast, sõpradelt ja pereliikmetelt 374 koroonaviirusega seotud tekstilist nalja, humoorikat pilti ja pildimakrot. Suure osa minu andmekogumist moodustasid kohalikke olusid kajastavad meemid, mis ringlesid Valgevene ja välismeedias. Kuigi Valgevene valitsuse eirav suhtumine pandeemiasse oli Ida-Euroopa riikide seas ainulaadne, viitas vaid 34 minu kogutud näidet konkreetselt olukorrale Valgevenes. Palju rohkem näiteid käsitles elu suletuses, kohustuslikku maskikandmist ning kaugtööd ja -õpet, kuigi neid meetmeid ei rakendatud riigis massiliselt. Vastuolu inimeste kogemuste ja riigis ringleva humoorika folkloori vahel illustreerib ilmekalt globaalse meedia mõju rahvaliku huumori väljendumisele. Need vernakulaarsed ilmingud osutavad tugevatele sidemetele Valgevene ja teiste riikide, eriti Venemaa meediakanalite vahel, kust paljud näited tõenäoliselt pärinevad.

Artikkel peegeldab ka tänapäeva folkloori üldist globaliseerumist ja digitaliseerimist, käsitleb uudisfolkloori (newslore) ja näitab, kuidas saab mõnesid folkloori üldomadusi rakendada vernakulaarse eneseväljenduse digitaalsetes vormides. Artikkel käsitleb ka globaalse ja paikse tasakaalu internetifolklooris.

Märksõnad: COVID-19, globaalsus, huumor, meemid, uudisfolkloor

\section{Sissejuhatus}

COVID-19 pandeemia kiire levik ning sellest tulenev majandus- ja sotsiaalkriis on inspireerinud palju loomingulisi ja humoorikaid reaktsioone kohalikul tasandil. Kuna miljonid inimesed olid 2020. aasta kevadel enamasti koduses isolatsioonis ja näost näkku suhtlemine oli piiratud, on paljud neist reaktsioonidest levinud internetis ja omandanud veebisuhtluse tüüpilise vormi, mille tulemuseks on peamiselt (audio)visuaalne sisu. Kriisi ülemaailmne iseloom tähendas, et paljud vernakulaarsed väljendid muutusid globaalseteks meemideks, samas teised omandasid meemilisi funktsioone kohalikul tasandil. COVID-19 kriisist sai seega viimase aja üks võimsamaid folkloori katalüsaatoreid. 
Folkloori on pikka aega peetud sotsiaalse tegelikkuse kommentaariks, milles selle loojad ja jagajad elavad (vt nt Dundes \& Pagter 1991: 20). Folkloorseid väljendeid peetakse igapäevaelus sügavalt juurdunuteks, kuigi folkloori ja sotsiaalse reaalsuse vaheline seos ei ole kaugeltki lihtne. Selle seose mitmetähenduslikkus torkab eriti silma naljafolklooris. Huumori loomupärane mängulisus muudab selle tõlgendamise sotsiaalse tegelikkuse kontekstis keeruliseks, kuid rahuldust pakkuvaks (tõlgendavate uuringute kohta vt nt Davies 1990, 1998, 2011; Oring 2003, 2016). Käsitledes huumorit selle sotsiaalses kontekstis paljastub mitte üksnes naljade ja muu humoorika folkloori tähendus, vaid süveneb ka arusaam kogukondadest, nende suhetest ning reeglitest ja tabudest, mis määravad nende käitumist (Davies 2011: 3).

Folkloori (eriti humoorika) tõlgendamise üks peamisi väljakutseid sotsiaalse tegelikkuse kontekstis on täpselt määratleda, millisest sotsiaalsest reaalsusest räägitakse ja kus see reaalsus peitub. Ülemaailmsete teabevoogude ajastul ei piirdu inimeste sotsiaalne suhtlemine nende asukohaga, vaid hõlmab ka laiemate, sageli riigipiire ületavate suhtluskanalite loomist ja säilitamist. Rahvusvaheliste uudiste kättesaadavus ja eelkõige digitaaltehnoloogia levik on aidanud kaasa info ja kommunikatsiooni rahvusvahelisustumisele. Folkloor kohaneb paratamatult nende oludega ja muutub seega ülemaailmse suhtlemise vahendiks.

COVID-19-ga seotud naljade Valgevenes levimise analüüs on huvitav näide infotehnoloogia mõjust rahvalikule eneseväljendusele. Erinevalt paljudest teistest riikidest ei võtnud Valgevene 2020. aasta kevadel nakkuse ärahoidmiseks kasutusele mingeid dramaatilisi meetmeid (nt isolatsioon, ulatuslik kaugõpe ja kaugtöö, avalike ürituste ärajätmine jne). Kuigi lõpuks mõned muutused tehti, ei muutunud valgevenelaste igapäevaelu nii drastiliselt kui paljude teiste (sealhulgas naaber-) riikide inimeste elu. Võiks eeldada, et ülemaailmsed COVID-19 teemalised naljad ja meemid, mis levisid vastuseks sotsiaalsele distantseerumisele, võinuks saada Ida-Euroopa rahva seas vähem vastukaja, sest piirangutel ei olnud elanikkonnale olulist mõju. Kuid nagu juba öeldud, on folkloori ja sotsiaalse reaalsuse seos harva lihtne. Käesolev artikkel analüüsib COVID-19 nalju Valgevenes ning osutab nende teemasid ja vorme mõjutanud teguritele. 


\section{Meetodid ja andmed}

Alljärgnev analüüs põhineb 2020. aasta veebruari lõpust juuli alguseni kogutud 374 naljal, pildil ja pildimakrol (pildid koos tekstipealdistega), valimis on 371 unikaalset teksti, kolm teksti on esindatud kahe versiooniga. Kõige aktiivsem aeg kõnealusel ajavahemikul oli märts ja aprill, mil õnnestus koguda 318 näidet. Enamikku näidetest jagasid minuga minu Valgevene sõbrad ja pereliikmed sotsiaalmeedia ja äppide privaatsõnumites. Teisi jagati avalikult minu sõprade sotsiaalmeedia lehekülgedel (Facebook ja VK) ${ }^{1}$ või Valgevene huumorile ja/või Valgevene uudistele pühendatud sotsiaalmeediarühmades. Salvestasin iga kirje andmekogusse, kasutades selle sisu kajastavaid märksõnu (nt maskid, eneseisoleerimine, kaugtöö jne).

Andmekogu näited erinevad leviku ja populaarsuse poolest: mõnda neist olen kohanud erinevatel sotsiaalmeedia platvormidel, samas teised näivad piirduvat konkreetsete rühmade ja nende vaatajaskondadega. Pärast teemade kaupa märksõnastamist (mõni näide kandis mitut teemat) kategoriseerisin teemasid populaarsuse alusel. Minu andmekogu kõige populaarsem teemavaldkond oli eneseisolatsioon (hõlmas ka karantiini ja sotsiaalset distantseerumist), mida esindas rohkem kui sada teksti. Populaarsuselt järgmine - ka kõige mitmekesisem - teemavaldkond hõlmas 34 kirjet, mis vihjasid koroonaviiruse pandeemiale Valgevenes. Järgnesid maskikandmine ning kaugtöö ja -õpe vastavalt 26 ja 22 näitega. Teisi teemasid esindas vähem kui 20 näidet. Mitmekesised olid ka naljade vormid: kuigi kõik näited minu kogus levisid rasterpiltidena, sisaldasid mõned neist teksti ainult ühe- või mitmevärvilisel taustal, samas teised olid pildimakrod ja väike rühm koosnes piltidest ilma tekstita.

Suurem osa minu andmekogu verbaalseid nalju ja pildimakrosid on vene keeles (kaks näidet on ka valgevene, kaks ukraina, kaks inglise ja üks poola keeles). Arvestades vene keele domineerimist Valgevenes on see ka mõistetav. Kuigi 2019. aasta rahvaloenduse kohaselt peab 54\% Valgevene elanikkonnast oma emakeeleks valgevene keelt, kasutab üle $70 \%$ elanikkonnast kodus vene keelt; linnaelanike seas, kelle hulka kuuluvad kõik mu informandid, on see protsent isegi kõrgem (NSK 2020: 44). Kuna vene ja valgevene keel on mõlemad Valgevenes ametlikud keeled, mida õpetatakse koolides, ning nende grammatikas ja sõnavaras on palju ühist, mõistab enamik (kui mitte kõik) Valgevene kodanikest mõlemat keelt, isegi kui nad kasutavad oma igapäevases suhtluses ainult ühte neist. Vene keele kasutamine ei ole Valgevenes tingimata seotud vene kultuuri või rahvaga; vene keele levimus Valgevenes tuleneb pigem erinevatest venestamiskampaaniatest, mida on läbi viidud alates 19. sajandist, samuti tihedatest poliitilistest, majanduslikest ja isiklikest kontaktidest valgevenelaste ja venelaste vahel. Lisaks erineb Valgevenes räägitav 
vene keel mõneti Vene Föderatsioonis kasutatavast keelest (Starichonok 2012: 78). Valgevenelased aktsepteerivad vene keelt kasuliku kommunikatsioonivahendina ning üksnes väike osa elanikkonnast peab seda ohuks valgevene kultuurile (Hentschel \& Kittel 2011: 74). Valgevene keel on rohkem levinud maapiirkondade elanike seas ja Lääne-Valgevenemaal, samuti pealinnas Minskis, kuigi valgevene keele kõnelejad moodustavad endiselt vähemuse ka nendes piirkondades. Isegi nende silmis, kes räägivad iga päev peamiselt vene keelt, on valgevene keelel oluline sümboolne väärtus, mis on seotud valgevene kultuuri ja etnilise identiteediga (Hentschel \& Kittel 2011).

Minu käsitlus tuleneb folklooriuuringutest ja ühendab COVID-19-ga seotud teemade kriitilise analüüsi nende analüütilise tõlgendamisega. See tugineb suures osas kvalitatiivsele analüüsile, võttes arvesse ka mõningaid statistilisi aspekte (nt teemade jagamine populaarsuse järgi). Peamiselt on tegemist juhtumiuuringuga, kuid järeldusi üldistatakse ka laiemas ulatuses. Metoodika tugineb huumoriuuringutele, võttes arvesse andmekogu mängulist iseloomu. Eelkõige olen analüüsinud tekstide humoorikust selgitavaid loogilisi mehhanisme. ${ }^{2}$ Olen kasutanud ka Christie Daviese (vt nt Davies 1990, 2011) ja Elliott Oringi $(2003,2016)$ käsitlust, mis põhineb naljade tekkimist ja levimist soosinud sotsiaalse, poliitilise ja kultuurilise konteksti analüüsil. Hinnates Valgevene valitsuse reageeringut COVID-19-le ja seda, kuidas pandeemia mõjutas kohalikku elu, võrdlesin seda ka naaberriikide (keelelise ja kultuurilise läheduse tõttu eriti Venemaa) olukorraga. Lisaks analüüsisin, kuidas oli teiste riikide pandeemiavastane poliitika esindatud Valgevene veebiuudistes ja sotsiaalmeedias.

\section{Folkloor globaalse meedia ajastul}

Folkloristid on pikka aega arutlenud folkloori leviku ja toimimise üle massimeedias (vt nt Dégh 1994; Mieder 2008) ja internetis (vt nt Bronner 2009; Blank 2009; Frank 2011; Peck \& Blank 2020). Digitaaltehnoloogiate areng on folkloristikat mõjutanud enneolematult. Folkloori olemus on pidevas muutumises, see kutsub folkloriste üles otsima uusi määratlusi, et jäädvustada folkloori toimimist nii internetis kui ka väljaspool seda (vt nt Bronner 2019).

Need muundumised on eriti kergesti tuvastatavad üldisel tasandil. Mõned traditsioonilised folkloorižanrid ja -tavad (naljad, legendid, vanasõnad jne) muutuvad ja kohanevad digitaalse keskkonnaga, samas on sündinud ka uusi žanreid, mis muutuvad üha populaarsemaks. Erinevalt suulise folkloori žanritest, mis tuginevad põhiliselt suulisele informatsioonile, on digimaailmas folkloor multimodaalne, ühendades verbaalse teksti heli ja visuaalsete elementidega. 
Tänapäeva folkloor on ületanud omaaegse suulise pärimuse piirid. Suurt osa nüüdisfolkloorist inspireerivad praegu maailmas toimuvad olulised sündmused, mida vahendatakse ja kajastatakse meedias. Sellist folkloori on nimetatud uudisfolklooriks (newslore - Frank 2004, 2011). Seda võib esineda paljudes folkloorižanrites (Kalmre 2017: 9) ja see näitab, kuidas ühiskonnas oluliste sündmuste kajastamine meedias kujundab nende vernakulaarseid peegeldusi. Samas võib uudisfolkloor olla õõnestav, sest “[s]ee rikub kaitse- ja valikuvabaduse reegleid, kui tegemist on võimunäitajate, kehaliste funktsioonide ja sotsiaalse konfliktiga viisil, mis võib tunduda anarhistlik, isegi nihilistlik, kuid on sisimas üsna moraalne: selle sihtmärk on silmakirjalikkus" (Frank 2011: 11). Uudisfolkloor tähendab seega väljakutset traditsioonilise meedia domineerimisele inimeste arvamuste kujundamisel olulistes poliitilistes, majanduslikes, sotsiaalsetes ja kultuurilistes küsimustes. Uudistekanalite ja vernakulaarse uudiste edastuste vaheline seos ei ole kaugeltki ühesuunaline: uudisväärse sündmuse tõlgendamine ja esindamine võib tuleneda nende kahe mõõtme vahelisest dialoogist, lisades neile mõlemale nähtavust (Dušakova 2017).

Digitaliseerimine on muutnud mitte ainult folkloori vormi ja teemasid, vaid ka selle edastamise võimalusi. Digitaalse levitamise silmapilksus on loonud sobiva keskkonna folkloori ülemaailmseks edasikandumiseks. Siiski sõltub folkloor paljuski selle kohalikust kontekstist ja hõlmab kultuurispetsiifilisi elemente, nagu keel, viited konkreetsetele poliitilistele, sotsiaalsetele või ajaloolistele küsimustele antud paikkonnas jne. Globaalse ja kohaliku vahelise tasakaalu üle arutletakse pidevalt kaasaegsete tehnoloogiate kättesaadavuse ja ülemaailmsete sidevõrkude leviku tõttu ja teisalt tänu keskendumisele kohalikule kultuurile.

Tähelepanuväärse osa veebisuhtlusest määravad endiselt folkloori iseloomulikud tunnused. Üks sellistest tunnustest on traditsioonilisus. Digitaalse folkloori kontekstis on traditsioonid suhteliselt hiljuti loodud ja need levivad peamiselt pigem ruumis kui ajas (Kaplan 2013). Internetifolkloori iseloomustab see, et paljud pärimusnäited omandavad kogu maailmas peaaegu silmapilkse populaarsuse, mis kaob sama kiiresti, kui kõnealused traditsioonid hakkavad tunduma ebaolulisena ja esiplaanile kerkib miski muu (Frank 2011: 7). Siiski, kui me vaatame traditsioone kui võrgus levivaid käitumismustreid, võime täheldada aastaid, kui mitte aastakümneid püsivaid nähtusi: selle, kuidas me postitame, jagame ja reageerime sisule, määravad internetisuhtluse traditsioonid. Asjaolu, et igaüks saab jagada internetis mida iganes ja pole rangeid eeskirju, kes peaks mida postitama, viitab sellele, et folkloori levikut veebis reguleerib pigem traditsioon kui institutsionaliseeritud reeglistik (Bronner 2009: 31). 
Traditsioonist määratletud korduvate ja pidevate mustrite kõrval mõjutab folkloori ka varieeruvus. Folkloori mitmekesisus on tingitud inimeste tegevuse erinevatest nii teadlikest kui ka alateadlikest teguritest. Suulise (mittedigitaalse) folkloori puhul hõlmavad esimesed (teadlikud) näited folkloori esitajate artistlikku kujutlusvõimet ja nad väljendavad oma individuaalset loomingulisust folkloori esitamisel; teisi iseloomustavad tahtmatud mugandused kohalike kultuuriliste, majanduslike ja muude asjaoludega, samuti mäluapsud, eriti pikkade folkloorižanrite puhul. Digitaalne folkloor on tahtmatute moonutuste suhtes mingil määral immuunne (Frank 2011: 9). Rahvaluule digitaalse jagamise protsessis esineb aga "ühismuudatus"; seda kasutatakse sageli kultuuripiiride tõmbamiseks ja folkloori kohandamiseks konkreetsete oludega (Blank 2009: 33).

Digitaalset folkloori levitades ja muutes osalevad inimesed oma kogukonna ülesehitamises. Sobitades individuaalset digireaalsust rühma kontseptsiooniga väitis Simon Bronner, et "jõuline rahvalik konstruktsioon, karastamaks digitaalekraani radikaalselt individualiseeritud maailma, on saitide kui selliste või kui nimekirjade ja võrgustike kaudu ühendatud rühmade looming" (2009: 30). Kõnealused võrgustikud on kanalid, mille kaudu teavet jagatakse, kuid selle funktsiooni täitmisel loovad nad ka kuuluvustunde ja toimivad ruumidena, kus võib levitada grupispetsiifilist folkloori. Uudisfolkloori saab kasutada rühma identiteedi kujundamiseks (Arhipova \& Radtšenko 2016: 116), sest teadlikkus teatud sündmustest ja sarnane ülevaade neist on üks peamisi mehhanisme, kuidas tunda ennast teatud sotsiaalse rühma liikmena.

Kogukonna loomine, samuti digitaalselt edastatava folkloori (eelkõige uudisfolkloori) traditsioonilisuse ja varieeruvuse säilitamine ei ole võimalik, kui puuduvad ühise kultuurilise taustaga kogukonna liikmed. Digitaalajastul on muutunud ka sellise tausta kujunemise protsess: teabe kohene kättesaadavus kogu maailmast võimaldab (vähemalt teoreetiliselt) mõista ja hinnata folkloori, mille juured ei ole oma paikkonnas ja mis põhineb pigem ülemaailmsetel sündmustel ja rahvusvahelistel uudistel. Aga kas see teoreetiline võimalus muutub praktikaks, kui folkloori edastatakse veebis? Kas inimesed on tõesti valmis jagama folkloori, mis ei viita nende igapäevaelule? Nendele küsimustele vastamiseks tuleb arvesse võtta mitmeid tegureid. Üks neist on kohalike ja ülemaailmsete kontekstide vastavus, mis muutub eriti nähtavaks, kui laiaulatuslikud sündmused toimuvad ülemaailmsel tasandil, näiteks 2020. aasta COVID-19 pandeemia. 


\section{COVID-19 vastukaja Valgevenes}

27. veebruaril 2020 testiti esimesel inimesel Valgevenes COVID-19. See isik ja kõik tema lähikontaktid isoleeriti kohe Minski haiglasse (Minzdrav 2020a). Esimestel nädalatel pärast esimest diagnoosi avastati ainult üksikuid uusi juhtumeid ning kõik diagnoositud ja nende lähikontaktid suunati haiglasse. Kui nakatunute arv suurenes, ${ }^{3}$ hakkas valitsuse lähenemine muutuma: kõigepealt hakati kodus ravima lähikontaktseid, seejärel patsiente, kes ei vajanud pidevat arstiabi. Nad pidid haiguse kestel viibima eneseisolatsioonis (lähikontaktsed 14 päeva), eneseisolatsiooni rikkujaid ähvardati trahviga.

Valitsuse ranged eeskirjad ei mõjutanud aga nende valgevenelaste elu, keda COVID-19 nakkus otseselt ei puudutanud. Tervishoiuministeerium avaldas mitmeid soovitusi sotsiaalse distantseerumise kohta (Minzdrav 2020b), need sisaldasid üleskutset, et kui tööle minemine ei ole otseselt vajalik, võiksid kodanikud jääda koju, osta esmatarbekaupu või saada ravi või muud elutähtsat abi. Dokumendis soovitati ka kaugtööd. Soovitusi ei jõustatud aga valitsuse tasandil ning jäeti rahva enda (sealhulgas tööandjate) otsustada, kas neid järgida on vaja. Paljud inimesed järgisid, püüdes vähendada oma sotsiaalseid kontakte, vältides restorane, spordirajatisi ja muid vaba aja veetmise teenuseid (Åslund 2020: 3), kuid oli ka soovituste eirajaid.

Mõned meetmed võeti tarvitusele ka kohalikul tasandil: näiteks 7. aprillil otsustas Minski linna täitevkomitee jätta ära kõik näitused ja laadad, sulgeda lugemissaalid ja avalikud raamatukogud, keelata külastused hooldekodudesse jne. Meetmed ei olnud siiski järjepidevad, näiteks Minski linn korraldas 9. mail Teise maailmasõja võidu mälestuseks iga-aastase võiduparaadi (Melnichuk 2020). Babruiskis, Magiljovi piirkonna rohkem kui 200000 elanikuga linnas, tegi peaarst 19. juunil ettepaneku kehtestada maskikandmise kohustus kauplustes, apteekides, pankades ja muudes kohtades, kus sotsiaalne distantseerumine ei ole võimalik (Bobrlife 2020). Magiljovi piirkonna Kirovi rajoonis kehtestati veelgi rangemad meetmed: lisaks kohustuslikule maskikandmisele piirati klientide arvu kauplustes, pankades ja muudes teenindusasutustes; kohvikud ja restoranid pidid olema suletud pärast kella 22 jne (Osipov 2020). Mõlemal juhul vastutasid aga meetmete rakendamise eest inimesed ja teenuseosutajad ise.

Kaugõppe ja -töö olukord jäi ka segaseks. Mõned ettevõtted, eriti IT valdkonnas ja teenuseosutajad, kellel ei ole vaja kliendiga silmast silma suhelda, valisid kaugtöö (Tomashevski 2020: 3). Kuid rohkem kui kaks kolmandikku kõigist tööandjatest (seisuga 28. märts 2020) jätkasid tööd tavapäraselt, kuigi paljud neist varustasid töökohad kätepuhastusvahendiga ja rakendasid 
täiendavaid meetmeid oma töötajate ohutuse suurendamiseks. ${ }^{4}$ Enamik koole jätkas kontaktõpet, kuid vanemad võisid viimasel kooliperioodil aprillist maini 2020 lubada oma lastel õppida kodus. Paljud ülikoolid läksid samuti kaugõppele (Tomashevski 2020: 1).

Valgevenes jätkus avalik-õiguslike ja eraasutuste toimimine peaaegu tavaliselt, seevastu naaberriigid võtsid kasutusele järsemaid meetmeid, et vältida COVID-19 edasist levikut. Valgevenega poliitiliselt ja majanduslikult tihedalt seotud Venemaal võeti 2020. aasta märtsi lõpus kasutusele eneseisolatsioon ja karantiin. Umbes samal ajal rakendati piiranguid ka naaberriigis Ukrainas. Kõik Euroopa Liidu liikmesriigid, kellel on ühine piir Valgevenega, nimelt Leedu, Läti ja Poola, olid samalaadsed meetmed tarvitusele võtnud juba 2020. aasta märtsi keskel.

Eeltoodu taustal esitas president Aleksandr Lukašenka mitu avaldust COVID-19 ja selle leviku kohta Valgevenes. Viiruse Valgevenes levimise esmases etapis nimetas ta sellega seotud hirme massimeedia põhjustatud psühhoosiks, mis tema väitel oli ohtlikum kui viirus ise. ${ }^{5}$ Kõneldes märtsi lõpus jäähokiareenil, väitis Lukašenka, et sport (eriti jäähoki) on parim viirusevastane ravim ja märkis, et areenil viirus talle silma ei hakanud (OTV 2020a). Ta (arvatavasti naljatades) avaldas ka arvamust, et nakatumise levikut võivad tõkestada saun, viin ja põllutööd (STV 2020a). Vaieldes vastu riigi lukustamisele või karantiini kehtestamisele osutas Lukašenka hukatuslikele tagajärgedele, mida sellised meetmed võivad majandusele tekitada (STV 2020e). Ta väitis ka, et "meie riigis ei ole keegi surnud koroonaviirusesse. ... Nad surid krooniliste haiguste tagajärjel" ja "mitte keegi ei sure meie riigis koroonaviiruse tõttu" (Valgevene Vabariigi president 2020a). Kui nakkuste arv hakkas Valgevenes suurenema, presidendi retoorika mõnevõrra muutus: ${ }^{6}$ ühes hilisemas kõnes ütles ta, et jälgib isiklikult olukorda ja palvetab, et see varsti läbi saaks. Mai lõpus (kui uute juhtumite arv oli haripunktis), ütles Lukašenka, et inimesed ei tohiks suhtuda koroonaviirusse kergelt, on vaja hoida, et Valgevenes oleks suremus madalaim maailmas ${ }^{7}$ (OTV 2020b). Juuli alguses, kui igapäevaste uute juhtumite arv vähenes, teatas ta, et kuigi võitlus viiruse vastu jätkub, “võime juba täna öelda: me oleme võitnud" (Valgevene Vabariigi president 2020b).

Valgevene valitsus käsitles COVID-19 pandeemiat nii omapäraselt, et see äratas paljude rahvusvaheliste uudisteagentuuride tähelepanu (vt nt Khurshudyan 2020; Kramer 2020; Melnichuk 2020; Rodgers 2020), kajastuste üldtoon oli negatiivne. Valitsuse tegevus lõhestas ka Valgevene ühiskonda: kuigi mõned kiitsid heaks Lukašenka otsuse karantiini mitte kehtestada, olid teised selle suhtes väga kriitilised, pidades seda elanikkonnale ohtlikuks (Jegelevicius 2020). Kontrast Valgevene lähenemisviisi ja naaberriikides tarvitusele võetud 
meetmete vahel, samuti üldsuse seisukohtade polariseerumine tervise-, majandus- ja sotsiaalkriisi ületamisviiside kohta tõi kaasa uudisfolkloori, millest suur osa oli humoorikas.

\section{Temaatiline mitmekesisus}

Käesoleva artikli põhirõhk on COVID-19-ga seotud huumori temaatilistel iseärasustel Valgevenes. Kuna pandeemia ja sellest tulenev kriis tungisid erinevatesse eluvaldkondadesse, hõlmas sellega seotud huumor samuti mitmeid teemasid. Seega sisaldab minu andmekogum mitte ainult otseseid COVID-19 pandeemia vastukajasid, vaid ka neid, mis on sellega tihedalt seotud: ostupaanika, majanduslikud ja poliitilised pinged, mis olid tingitud haiguse levikust, võltsuudistest jne.

Andmeid analüüsides kasutan terminit "huumor" üldmõistena, mis sisaldab erinevaid nähtusi alates heatahtlikust naljast iroonia ja sarkasmini. Need erinevad huumoriastmed peegeldavad digitaalmeedias leiduvaid erinevaid lähenemisviise COVID-19 kriisile.

COVID-19-ga seotud huumori teemasid analüüsides on vaja arvesse võtta ka nende ringluse diakroonilist aspekti. Mõned teemad olid kogumise ajal püsivad. Kõige rohkem tähelepanu pälvisid haiguse leviku vältimiseks kasutusele võetud meetmed (maskikandmine, käte pesemine ja desinfitseerimisvahendi kasutamine jne) ning kaugõpe ja -töötamine. Muude teemade ringlusaeg jäi napimaks. Nende seas olid ostupaanika (märtsikuu teise poole meelisteema), vandenõuteooriaid (teema tõusis esile mai alguses, püsis ka juunis ja juulis), esimeste plahvatusliku COVID-19 levikuga riikide Hiina ja Itaalia pihta suunatud naljad (märtsis ja aprilli alguses), keskkonnaolude paranemine tööstustegevuste languse ajal (märtsi keskpaigast aprilli keskpaigani) ja nii edasi. COVID-19 seotud naljade teemavaldkonda võib seega pidada dünaamiliseks ja vastavaks hetkeolukorrale.

\section{Üldised teemad: eneseisolatsioon, kaugõpe/-töö ja maskikandmine}

Kõige populaarsem teema, mille kohta kogusin rohkem kui sada teksti, oli seotud sotsiaalse distantseerumise, eneseisolatsiooni ja karantiiniga. Tekstides kajastati mänguliselt karantiini võimalikke tagajärgi ja asjaolu, et inimesed pidid kodus olema palju rohkem kui nad seda tavaliselt teevad. Tagajärjed: probleemid pereelus, alkoholi ja toidu liigne tarbimine, vaimse tervise probleemid jne. 


\section{Подозреваю, что вирус}

женских рук дело :

1. Умирают в основном

мужчины

2. Отменены все матчи,

3. Закрыты бары, увеселительные учреждения

4. Ну а те, кто в живых остался сидят дома с женами

Joonis 1. Ma kahtlustan, et viirus [COVID-19] on naiste kätetöö: 1. Enamasti surevad [selle tõttu] mehed. 2. Kõik spordiüritused on tühistatud. 3. Baarid ja meelelahutusasutused on suletud. 4. Need, kes on veel elus, on kodus koos oma naisega. Saadud Valgevene vastajalt (mees, 40 aastat vana) Facebooki privaatsõnumis 1. aprillil 2020.

Iroonilises võtmes on mõni pandeemiaga seotud "probleem" tegelikult isolatsiooni positiivse mõju kohta:

Пока остальной бизнес хоть как-то барахтается, бизнес домушников лёг полностью.

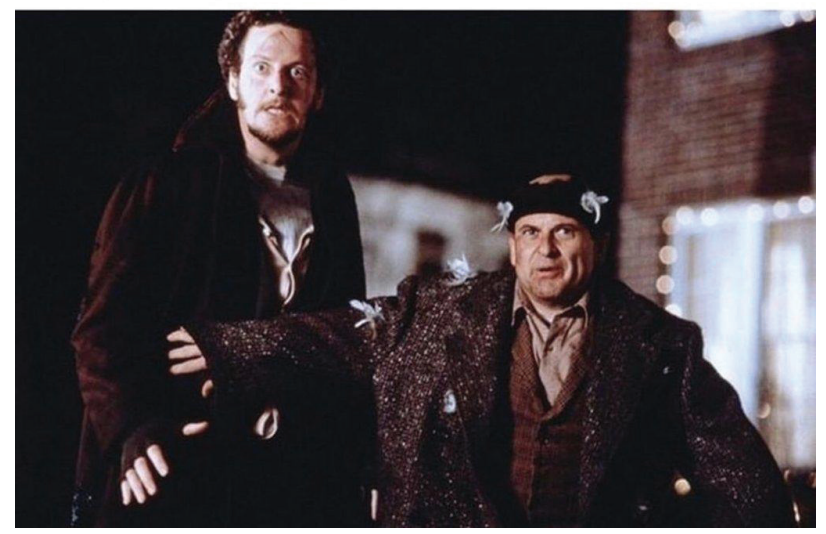

Joonis 2. Kui teised ettevõtted võitlevad veel, et ellu jääda, on murdvaraste äri täielikult rikutud. Saadud Valgevene vastajalt (naine, 43 aastat vana) Viberi kaudu 31. märtsil 2020. 
Naljade sihtmärgiks sai ka asjaolu, et kodus püsimine (mis seostub tavaliselt tegevusetuse, mitte aktiivse probleemilahendamisega), on seni osutunud kõige tõhusamaks viiruse leviku tõkestajaks:

Joonis 3. Ülemine tekst: "On saabunud aeg, mil maailma saab päästa kodus istudes ja mitte kuhugile minnes." Alumine tekst: "Ma olen selleks sündinud."17. märts 2020, https: / / vk.com / minsk.stolica? $z=$ photo$74552614 \_457289828 \% 2 F w a$ ll-74552614_285138 (vaadatud 12.02.2021).

\section{НАСТАЛ МОМЕНТ, КОГДА М口ЖН口 СПАСТИ МИР, СИДЯ ДОМА И НИКЧДА НЕ ВЫХपДЯ}

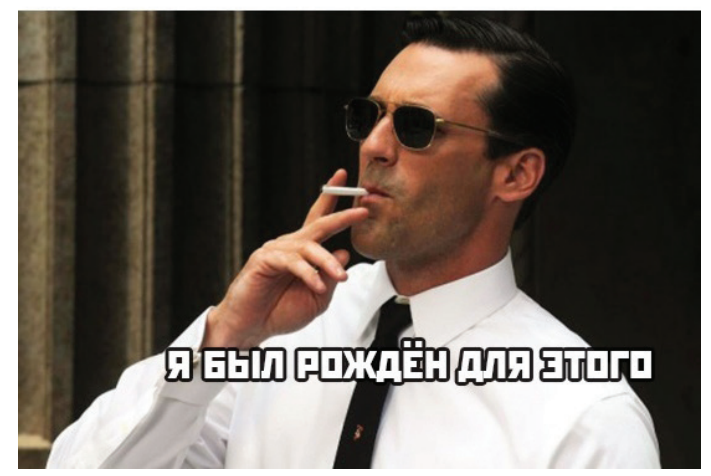

Naljade allikas oli ka pikalt kodus olemise mõju vaimsele tervisele:

ЕСТЬ И ХОРОШИЕ НОВОСТИ.

TEПЕРЬ ВАША КУКУХА НЕ СМОЖЕТ ОТЬЕХАТЬ БОАЕE ЧЕM HA 100 METPOB ОТ ДОМА

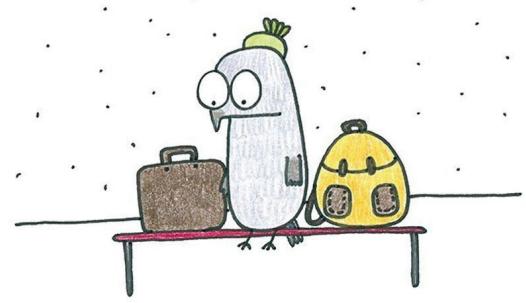

Joonis 4. "On ka häid uudiseid. Nüüd ei saa kägu [hulluks] minna kaugemale kui 100 meetrit kodust.”Pealdises kasutatakse sõnamängu. (ваша кукуха не сможет отьехать tähendab otsetõlkes "teie kägu ei saa lahkuda". Idioom "üks kägu on lahkunud” tähendab nii Valgevenes kui ka Venemaal, et inimene on hulluks läinud. Seda pilti jagas minuga VK privaatsõnumis 32aastane naine. 
Huvitaval kombel põhineb selle näite nali mitmes Venemaa piirkonnas kehtestatud korral, et inimene võib lahkuda kodunt vaid selleks, et minna tööle, kauplusse, haiglasse, prügi välja viima või koera jalutama mitte kaugemale kui sada meetrit kodust (Girsh 2020). Valgevenes selliseid meetmeid ei kehtestatud, kuid nalja mõistmiseks pole tingimata vaja teada Venemaa konteksti, sest sarnased meetmed kehtestati paljudes maailma riikides ja neid kajastati Valgevene uudistes.

Selle näite (ja veel mitme) põhinemine konkreetselt Venemaa kontekstil ei ole juhuslik. Venemaa meedia on Valgevene meedias vägagi tuntav; lisaks saavad paljud valgevenelased infot Venemaa olukorrast oma sõprade ja pereliikmete käest, kes seal elavad. Tihedad sidemed võivad kaasa tuua ka mitmemõttelisust: ühest küljest ei tundu Venemaa kontekst võõras, kuid teisest küljest erinevad naljad oluliselt valgevenelaste kogemustest COVID-19 pandeemia ajal. Lähedaste naabrite üle nalja visates teadvustavad valgevenelased selle vastuolulisust, kuid samal ajal on neil võimalus psühholoogiliselt nalja reaalsusest distantseeruda.

Paljudes eneseisolatsiooni ja karantiini teemalistes naljades tekitab humoorika efekti liialdus. Koduste piirangute rangust tähtsustatakse üle, samuti kodusviibimise (nii positiivseid kui ka negatiivseid) oletatavaid tagajärgi. Isolatsiooni kestust oli raske ennustada, eriti pandeemia algfaasis, mil paljudes riikides pikendati isolatsiooni mitu korda; selle mõju füüsilisele ja vaimsele heaolule ei olnud veel kindlaks tehtud. Ulatusliku karantiini ebakindlus ja mitmetähenduslikkus tekitasid viljaka huumoripinnase.

Paljusid nalju inspireerisid äkki tavaliseks saanud kaugtöö ja -õpe. Märkimisväärne osa naljadest mängis ideega teha kaugtööd sfäärides, kus see on ilmselgelt võimatu:

Joonis 5. “Maša, tule, vii ära!” Jagas 43aastane naine Viberi privaatsõnumis 6. aprillil 2020.

- Маша, иди забирай!

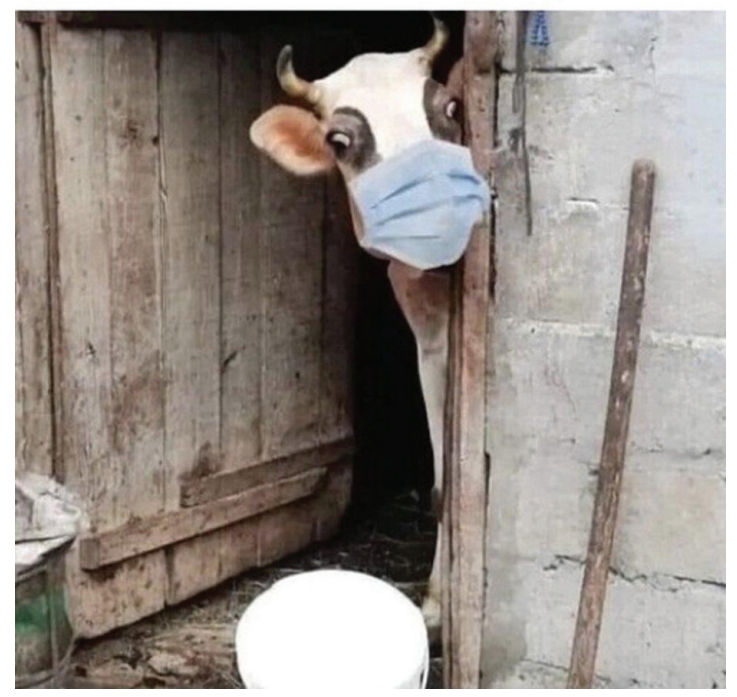


Digitaaltehnoloogia kasutamine (ja vältimatud vead), millest oli saanud kaugtöö ja -õppe asendamatu osa, tekitas juhtidele ja haridustöötajatele väljakutseid (vt nt Ivaniuk \& Ovcharuk 2020), mis sai ka naljade sihtmärgiks:

Joonis 6. "Kas kõigil on heli?". Twitter, 8. aprillil 2020, https: / /twitter.com / blisch / status / 1247973180268072961 / photo/ 1 (vaadatud 12.02.2021).

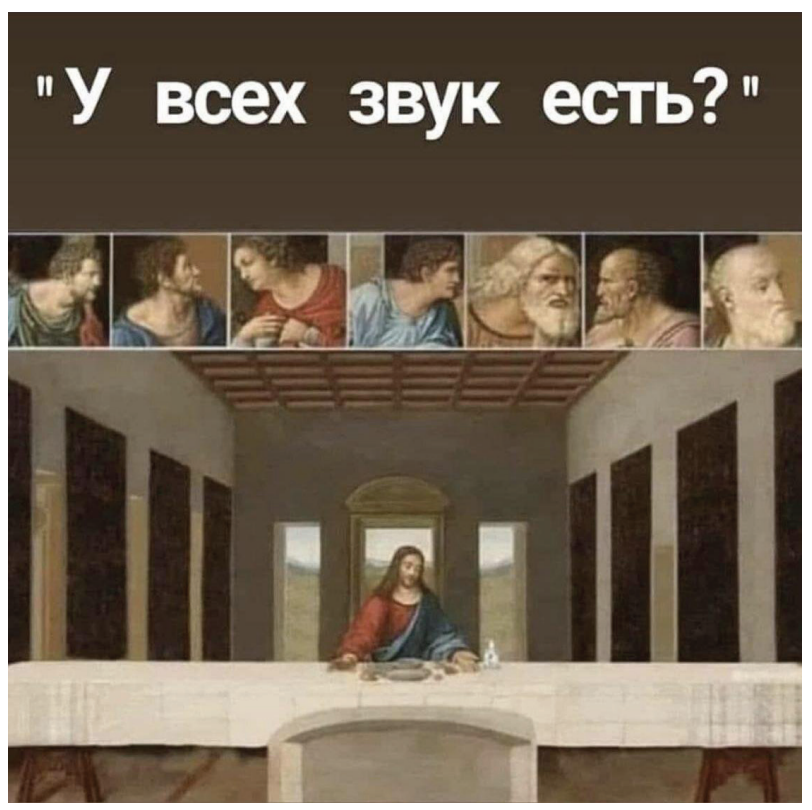

Digitaalselt vahendatud haridus inspireeris mõtteid, kuidas kohandada vanu tavasid ja rituaale uue reaalsusega:

\section{Примерно так будет выглядеть выпускной у 11-классников в 2020}

Joonis 7. "Umbes nii hakkavad välja nägema lõpuaktused 2020.” Ülevalt vasakul: "Sa näed hea välja." Üleval paremal: "Tänan, kas me tantsime?" All vasakul: "Ma olen üles kasvatanud nii armsad lapsed, ma hakkan nutma." All paremal: "Nii, Sergei Petrovitš, terviseks.” - "Tööõpetuse ja kehakultuuri eest!" [Need on kaks ainet, mida Valgevene koolides õpetavad peaaegu ainult mehed, teised kooliõpetajad on naised]. 30. märts 2020, https: / / vk.com $/$ minsk. stolica? $z=$ photo 74552614_457290441\%2Falbum74552614_00\%2Frev (vaadatud 12.02.2021).

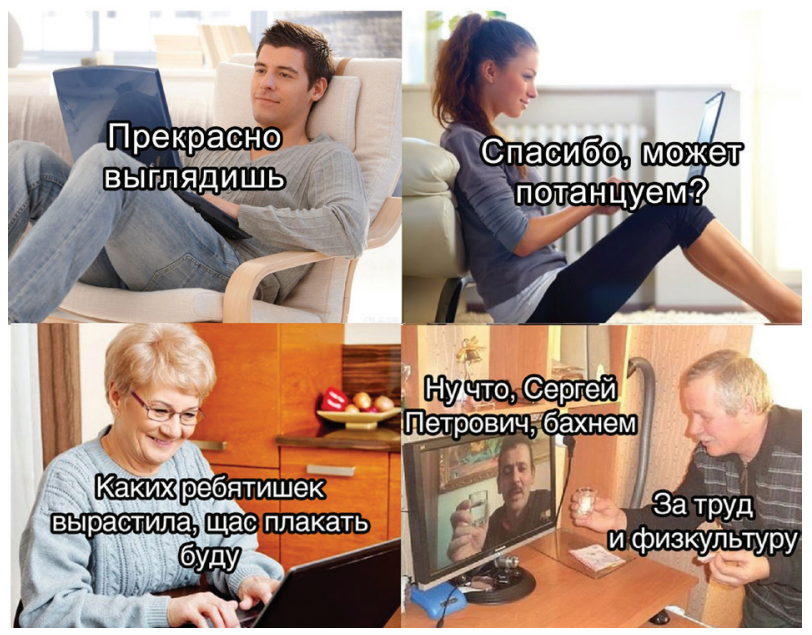


Kaugõppest ja -tööst sai üks COVID-19 pandeemia sümboleid. See mõjutas maailmas miljoneid inimesi ja ajendas neid muutma oma argirutiini, mõjutas töö- ja õppe-eetikat ning tõi tähelepanu keskpunkti kommunikatsioonitehnoloogia. Tänapäeva infotehnoloogiale keskenduv huumor ei ole kindlasti uus nähtus; see on olnud populaarne nii naljade tootmisel kui ka jagamisel, samuti naljade sihtmärk. Tehnoloogiaalaste naljade populaarsus tuleneb osaliselt asjaolust, et sellised naljad kajastavad ka inimesi ja inimlikkust ning tehnoloogia keskset rolli inimeste elus (Shifman \& Blondheim 2010). See aspekt muutub silmatorkavaks ajal, mil inimeste sõltuvus tehnoloogiast on kiiresti ja dramaatiliselt suurenenud, tekitades uusi väljakutseid mitte ainult tehnilisel, vaid ka sotsiaalsel, psühholoogilisel ja kultuurilisel tasandil.

Samal ajal kui kogu maailma arstid, proviisorid ja keemikud otsisid tõhusaid viise COVID-19 leviku tõkestamiseks, lõid ja levitasid miljonid arvutikasutajad naljapilte ja -tekste kõige populaarsemate ennetusmooduste kohta. Näomaskid ja kätepuhastusvahendid kuulutati koos sotsiaalse distantseerumisega kõige tõhusamateks viiruse leviku aeglustamise vahenditeks:

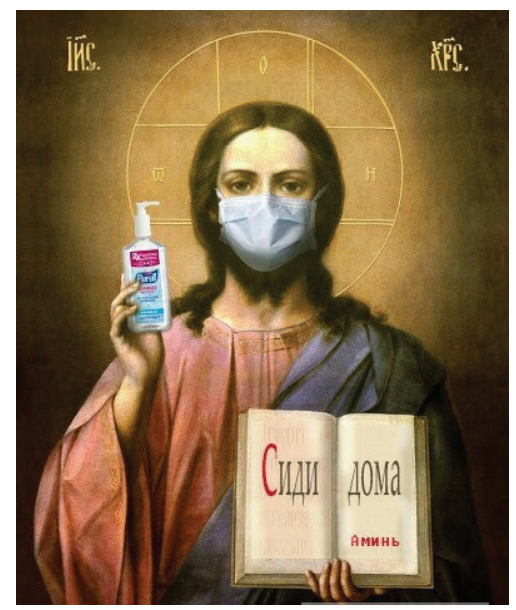

Maskikandmine muutus asendamatuks paljudes situatsioonides, kus seevõis varem tundudakohatu:

Joonis 9. Seda pilti jagas 24. aprillil 2020 Viberis 43aastane naine. Kiri ladina (mitte kirillitsa) tähestikus näitab, et selle pildi makro "imporditi" Valgevenesse väljastpoolt, kuid lühike ja arusaadav tekst ei vajanud edasist kohandamist.
Joonis 8. Raamatu tekst: "Istu kodus. Aamen". 11. Aprill 2020, https: / / vk.com / belteanews? $z=$ photo82476651_457277154\%2Fwall-82476651_470979 (vaadatud 12.02.2021).

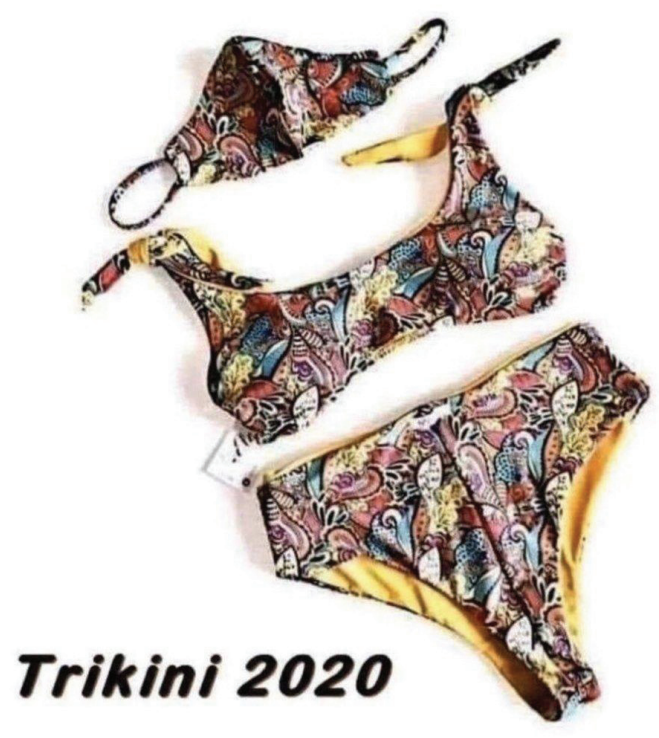


Sama hüperboolselt, nagu kujutati eneseisolatsiooni, kujutati liiase irooniaga ka enda kaitsmist COVID-19 eest:

Joonis 10. "Küberpunk, mida me väärime." 28. veebruar 2020, https://twitter.com/ Daily_minsk/status / 1233338745820196864. Taustal võib näha Valgevene Riikliku Tehnikaülikooli peahoonet; selle õppeasutuse üliõpilane oli esimene inimene Valgevenes, kellel päev enne postituse tegemist tuvastati COVID-19 positivive test.

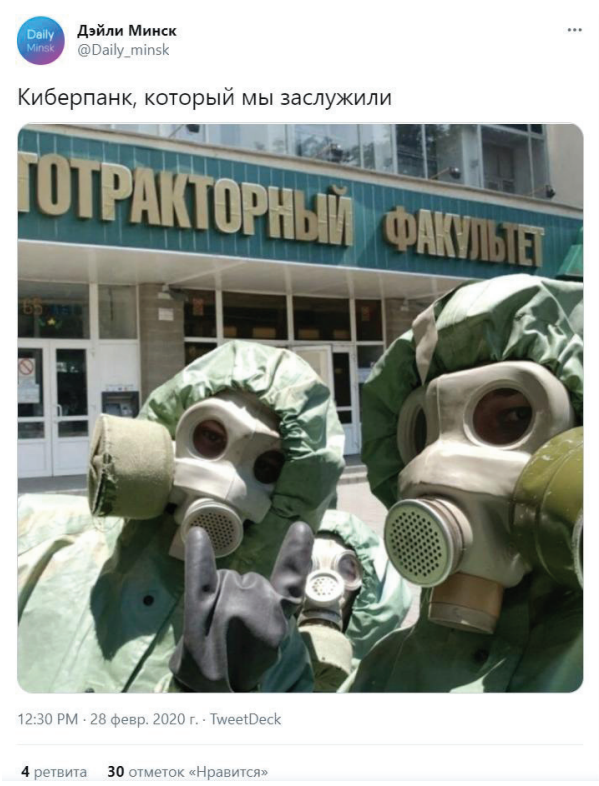

Humoorikad kommentaarid maskide, kätedesinfitseerijate ja teiste kaitsevahendite kohta on peegeldus, kui ebaproportsionaalselt suurt rolli hakkasid need asjad meie elus mängima (võrreldes COVID-19 eelse ajaga). Teisest küljest peegeldab nende kujutamine tuttavate esemete (nagu bikiinid, vt joonis 9) või isegi pühade kujutiste (vt joonis 8) osana nende jätkuvat kohandamist ja üha suuremat aktsepteerimist igapäevaelu normaalsete elementidena (arutelu vt Morris 1993).

Kodus töötamise / kaugõppe kahjulikud kõrvalmõjud (liigsöömine, alkoholitarbimine, pereprobleemid) olid reaalsus, mis oli arusaadav ja tuntav kogu maailmas; samuti sellised argielu muutused nagu maskikandmine ja sage kätepesu. Neil teemadel tehti ja jagati nalju paljudes keeltes ja variatsioonides ning sageli oli vaja vaid pisikest kohandamist, et nali oleks arusaadav teises paikkonnas. Lisaks nendele universaalsetele küsimustele seisis iga riik silmitsi oma spetsiifiliste küsimustega. Ka need said paratamatult humoorikate kommentaaride sihtmärgiks.

\section{Rahvusliku tooniga huumor}

Ainult 34 näidet (umbes 9\% minu andmekogust) kajastas olukorda Valgevenes ja seda, kuidas pandeemiat riigis käsitleti. Enamik neist on sarkastilised Valgevene valitsuse ebatavalise ja vastuolulise lähenemisega COVID-19-le. 
Mõned näited olid suunatud konkreetselt Valgevene presidendi viiruseteemalisele retoorikale:

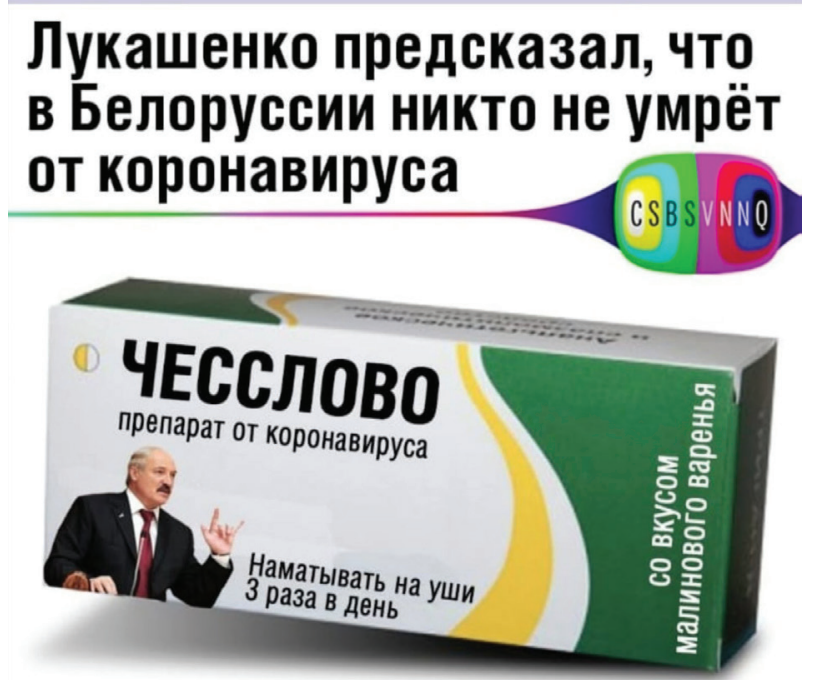

\section{СПРАШИВАЙТЕ В АПТЕКАХ БЕЛАРУСИ}

Joonis 11. Ülemine tekst: "Lukašenka on ennustanud, et keegi ei sure Valgevenes koroonaviirusse." Pakend: "Minu sõna: koroonaviiruse ravim. Panna kolm korda päevas kõrvadele. Vaarikamoosi maitse." Alumine tekst: "Küsige seda Valgevene apteekidest." Kirje saadi Viberi kaudu 27aastaselt naiselt 15. aprillil 2020.

See näide kubiseb keelelistest ja kultuurilistest viidetest. Väljend "panna kõrvadele" viitab venekeelsele idioomile вешать лапшу на уши (otsetõlkes "riputada nuudleid kellegi kõrvadele"), mis tähendab valetamist. "Vaarikamoos" on viide populaarsele sotsiaalmeedia kontole "Tee vaarikamoosiga" (Чaŭ з малинавыли варэннел), mis tegeleb Valgevene uudiste humoorika (sageli sarkastilise) esitamisega. Konto nimi on viide president Lukašenka vastusele ajakirjaniku hoiatusele, et tema küsimus võib olla karm: president soovitas, et ajakirjanik peaks võtma tassi teed vaarikamoosiga ja pidas lühikese kõne sellise tee ülistuseks. Kuigi suurt osa huumorist võiks hinnata iga vene keele kõneleja, lisab valgevene keele täpsem tundmine (nt vaarikamoosi viide) selle näite huumorile lisakihte.

Muude naljade keskmes on Aleksandr Lukašenka retoorikale viitamise asemel rahva üldine reaktsioon pandeemiale ja valitsuse meetmetele, mida peetakse ebapiisavaks: 
Joonis 12. "Vaat, mis ma välja olen mõelnud: joodiruudustik. - Aleksandr Grigorjevitš [Lukašenka ees- ja isanimi], võib-olla aitab juba, augustikuu, 300 inimest on järel [riigis].” Valgevene Viberi kaudu jagas 53aastane naine 4. aprillil 2020.

Teised naljad paigutasid Valgevene olukorra laiemasse geopoliitilisse konteksti, kommenteerides humoorikalt riigi pandeemiapoliitika rahvusvahelist vastuvõttu.
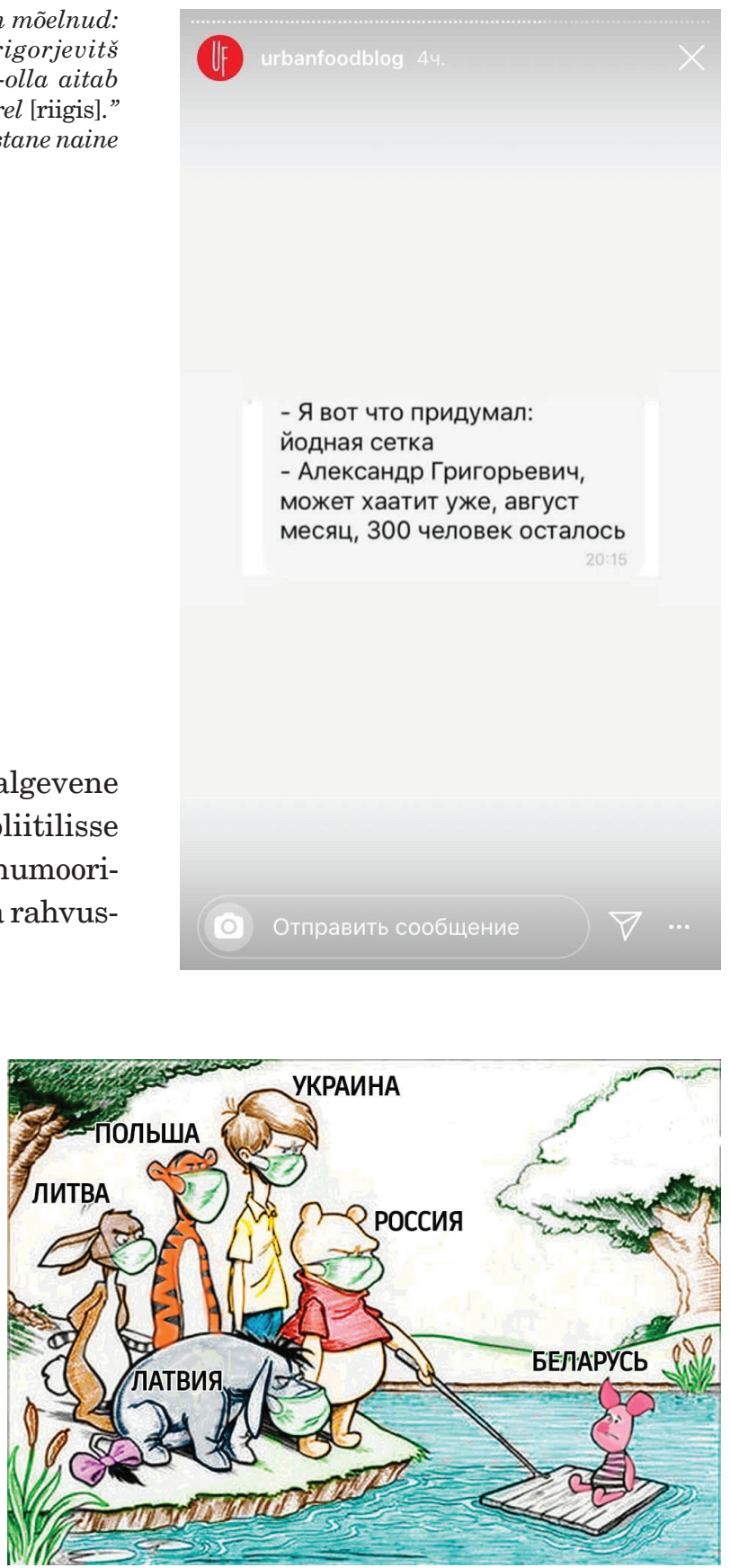

Joonis 13. Kaldal olevad tegelased on märgistatud "Leedu", "Poola", "Ukraina", "Venemaa", "Läti" (kõik riigid, millel on Valgevenega ühine piir). Parvel olev notsu kannab märget "Valgevene" (postitatud 19.03.2020 https://vk.com/belmems? z=photo-83285883_457239378\%2Falbum83285883_00\%2Frev-vaadatud 15.02.2021). 


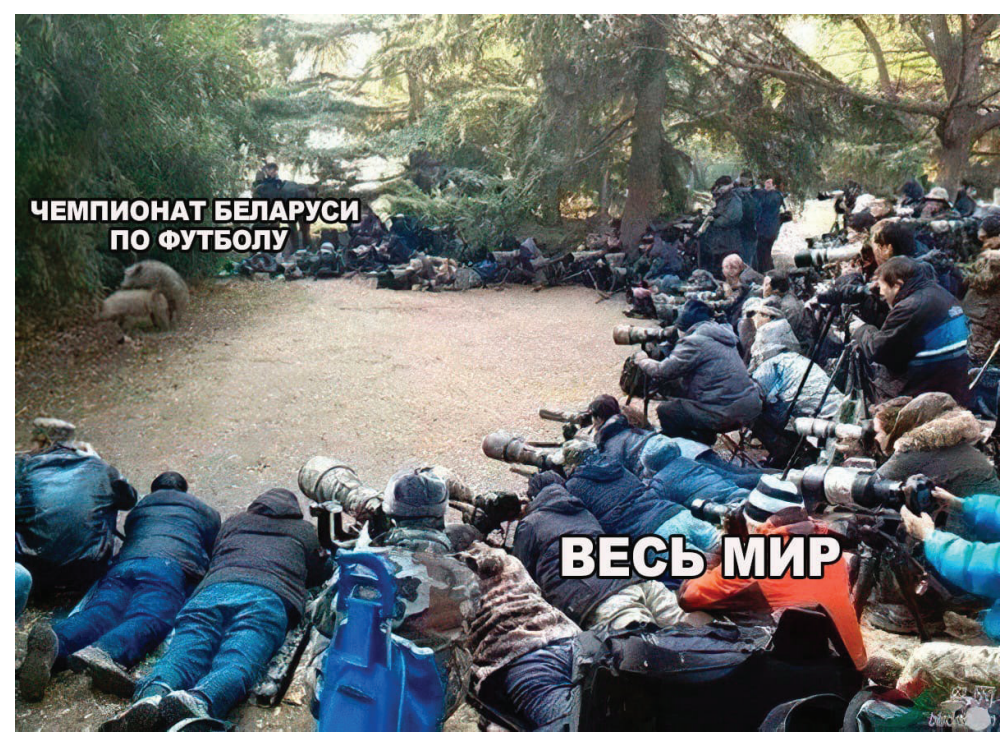

Joonis 14. Loomade kohal kirje: "Valgevene jalgpalli meistrivõistlused" ja fotograafidel: "Kogu maailm" (postitatud 21.03.2020 https://vk.com/belmems? z=photo83285883_457239387\%2Falbum-83285883_00\%2Frev-vaadatud 15.02.2021).

Väiksem rühm huumorinäiteid ei peegeldanud sõna otseses mõttes Valgevene lähenemist COVID-19-le, vaid mõningate populaarsete COVID-19 naljade kohandusi Valgevene kontekstis:

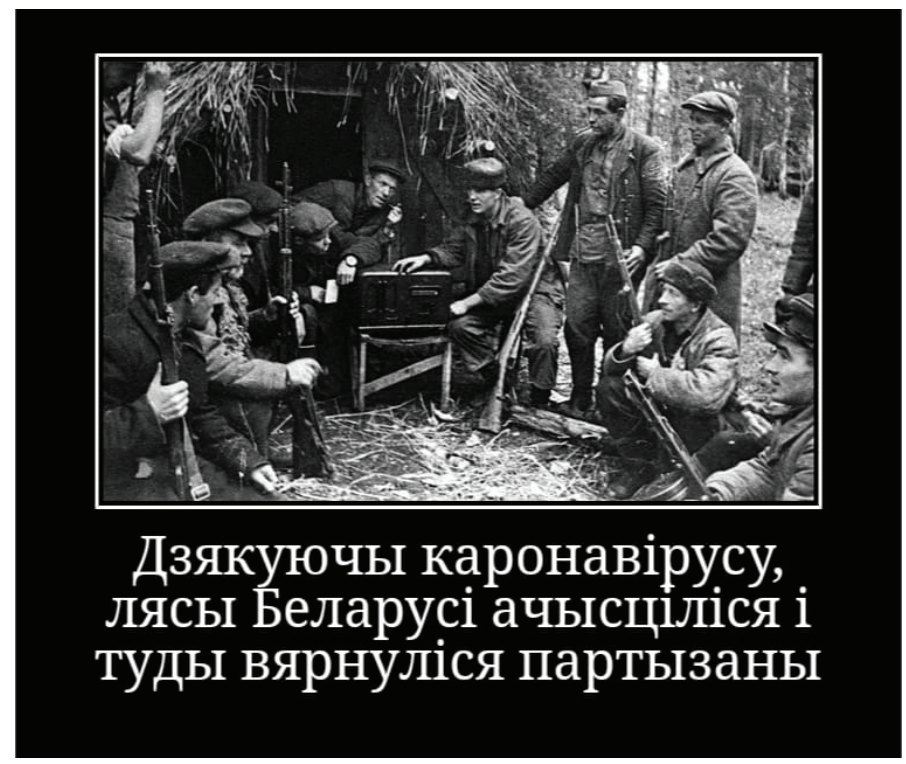

Joonis 15. "Tänu koroonaviirusele paranevad Valgevene metsad, sinna on naasnud partisanid" (postitatud 2.04.2020 https: / / www.facebook.com / photo.php?fbid=3189 266957751392\&set=a.997538106924299\&type=3\&theater - vaadatud 15.02.2021). 
Siin võime näha kohaliku ja globaalse meediadiskursuse segunemist. Kohalikku aspekti esindab valgevene keele kasutamine ja viide partisanidele, mis on seotud asjaoluga, et Teise maailmasõja ajal oli väga aktiivne partisanisõda saksa okupatsiooni vastu - hiljem sai sellest asjaolust rahvusliku identiteedinarratiivi osa. Globaalne aspekt tuleb ilmsiks tiitri struktuurist. Kujutis on modelleeritud "loodus on tervenemas" teemaliste meemide alusel. See on pandeemia esimestest päevadest sotsiaalmeedias ringlema hakanud arvukate tööstustegevuse pidurdumise tagajärjel keskkonna paranemist kinnitavate küsitava väärtusega postituste paroodia.

Nii globaalsete huumoritrendide lokaliseerimine kui ka Valgevene COVID-19 pandeemiale lähenemise eksootilisus on rikastatud kohalike viidetega, ent mõlemad näitavad ka valgevenelaste teadlikkust ülemaailmsetest sotsiaalsetest, poliitilistest ja folkloorsetest protsessidest. Riigispetsiifiline COVID-19 huumor Valgevenes on naljakas üksnes siis, kui see paigutub maailmas pandeemia põhjustatud muutuste laiemasse konteksti.

\section{Järeldused}

Sõltumata sellest, kas usutakse, et massi- ja rahvakultuuri vahel on järsk erinevus või nähakse omavahel lõikuvaid ja üksteist täiendavaid seisukohti (vt arutelu Blank 2012: 3), on võimatu eitada massi- ja sotsiaalmeedia mõju tänapäeva folkloorile, eriti peamiselt virtuaalmaailmas eksisteerivale folkloorile. Uudistesaated mitte üksnes teavitavad inimesi sündmustest, vaid kujundavad inimeste ettekujutust nendest sündmustest ja käivitavad kohalikke vastukajasid. Tänu Web 2.0 tehnoloogiale võivad vastukajad levida kiiresti ja ületada nii riigi- kui ka keelepiire. Nende sisu, vorm ja levitamismehhanismid järgivad teatud mustreid (kooskõlas folkloori traditsioonilisusega), kuid teevad läbi ka variatsioone. Sarnaselt nendele, kes jagavad suulist rahvaluulet, loovad online folkloori jagajad erineva lähedusastmega rühmi ja kogukondi.

Folkloor on sügavalt juurdunud teatud piirkonnas, selle kultuuris ja keeles. Kuid ka globaalsel meedial on folkloori levimisele sama oluline mõju kui kohalikel sündmustel, millega inimesed oma igapäevaelus kokku puutuvad. See tuleb eriti ilmsiks niisuguste suurte poliitiliste, majanduslike, sotsiaalsete, ökoloogiliste ja tervisekatastroofide ajal nagu COVID-19 pandeemia. Kui miljonid inimesed kogu maailmas seisavad silmitsi sarnaste ohtude ja probleemidega, reageerivad nad neile tõenäoliselt ühtmoodi. Seda kajastab COVID-19 kohta laialt levitatav humoorikas folkloor, mis käsitleb pandeemiat ja selle tagajärgi. Kuigi mõnes riigis võivad inimeste argikogemused erineda teatud globaalsetest suundumustest, on neil inimestel siiski vajalikud taustateadmised, et mõista (ja hinnata) nendel suundumustel põhinevat huumorit. Jagades huumorit, mis 
keerleb sündmuste ümber, mis on väljaspool nende otsest reaalsust, näitavad inimesed teadlikkust globaalsetest probleemidest, samuti saavad nad võimaluse teha nalja kaugemate ja seetõttu vähem traumaatiliste sihtmärkide üle.

Sellise globaalse folkloori kõrval leidub ka humoorikaid vastukajasid, mis kajastavad olukorda konkreetses paikkonnas. COVID-19 pandeemia ajal võttis iga riik kasutusele oma meetmed ja neist mõned on käivitanud humoorika folkloori loomise. Siiski ei ole isegi kohaliku "maitsega" huumor alati täiesti kohalik, seda täiendab laiem kontekst. Kohalike sündmuste ja meetmete grotesksus või absurdsus ilmneb ainult võrdluses teiste riikide lähenemisviisidega.

Minu andmekogus sisalduva kohaliku huumori väikest osakaalu võib seletada mitme teguriga. Üks neist on seotud andmete kogumisega: ülemaailmsete folkloorinäidete esinemissagedus võis tekkida minu pere ja sõprade individuaalsete eelistuste tõttu, kes olid abiks näidete kogumisel, sama kehtib sotsiaalmeedia rühmade kohta, kus ma laiemalt publikult nalju otsisin. Teine selgitus tuleneb COVID-19 kriisi olemusest: vaatamata erinevatele kohalikele lahendustele on see kogu maailma mõjutav ülemaailmne oht. Selle negatiivse mõju vähendamise teadaolevad meetmed (sotsiaalne distantseerumine, kaugtöö ja -õpe, maskid jne) kehtivad kõikjal maailmas ning võivad saada populaarseteks naljateemadeks isegi riikides, kus neid meetmeid laialdaselt ei propageeritud ega rakendatud. Lühidalt öeldes nõuavad ülemaailmsed väljakutsed ülemaailmseid vastuseid, samuti ülemaailmset huumorit.

Naljade uurimine tänapäeva meedia kontekstis aitab paljastada olulisi seoseid sündmuste meediakajastuste ja nende folkloorsete vastukajade vahel. Valgevene COVID-19 huumori juhtumiuuring võib olla illustreeriv näide ametliku ja rahvaliku ning kohaliku ja ülemaailmse tihedast ja mitmetähenduslikust seosest. Selle uuringu tulemusi võiks testida teiste kontekstide suhtes, et süvendada arusaamist folkloori ringluse protsessidest tänapäeva maailmas, eriti ülemaailmse kriisi ajal. Tuleviku teadusuuringute muud võimalikud suunad hõlmavad laiemat ajaraamistikku ning COVID-19 naljade võrdlemist eri perioodidel, kultuuridevahelist ristvõrdlust, digitaalse huumori detailsemat üldist ja temaatilist liigitamist ning paljude muude põnevate aspektide uurimist.

Tõlkinud Asta Niinemets

\section{Tänusõnad}

Kirjutis on seotud Eesti Kirjandusmuuseumi uurimisprojektiga EKM 8-2/20/3 "Folkloori narratiivsed ja uskumuslikud aspektid" ja EKKD65 "Kuidas allikatest saab kultuur: eesti aines Eesti Kirjandusmuuseumi kogudes ja andme- 
baasides", selle valmimist toetas Euroopa Liit Euroopa Regionaalarengu Fondi kaudu (Eesti-uuringute Tippkeskus, TK 145). Tänan anonüümseid retsensente kommentaaride ja ettepanekute eest.

\section{Kommentaarid}

1 VKontakte (rahvusvaheline lühend VK) on venekeelsete inimeste seas populaarne sotsiaalvõrgustik, mille struktuur sarnaneb Facebookile.

${ }^{2}$ Loogiline mehhanism on üks verbaalse huumori üldteooria elemente. Loogiliste mehhanismide ja nende taksonoomia kohta vt Attardo et al. 2002.

3 Vastavalt ametlikule statistikale osutus pandeemia tipus (6.-27. maini) iga päev positiivseks rohkem kui 900 inimese test.

4 Uuringu viis läbi üks Valgevene suurimaid uudisteagentuure TUT.BY (täpsemalt vt finance.tut.by 2020).

5 Lukašenka üks esimesi psühhoosi mainimisi salvestati 19. märtsil 2020 (STV 2020b). 28. märtsil 2020 nimetati paanikat hullemaks kui viirus ise (STV 2020c). Üks mainimine oli seotud sidruni ja ingveri ostupaanikaga (STV 2020f).

${ }^{6}$ Lukašenka retoorika muutusi märtsist aprillini 2020 on võimalik jälgida Office life 2020.

7 Esimest korda öeldi seda 31. märtsil 2020 (STV 2020d).

\section{Kirjandus}

Arhipova, Aleksandra \& Radtšenko, Daria 2016. Newslore v sovetskom i postsovetskom prostranstve: ot sostavitelei. Antropologicheskii forum 31, lk 115-118.

Åslund, Anders 2020. Responses to the COVID-19 crisis in Russia, Ukraine, and Belarus. Eurasian Geography and Economics 61 (4-5), lk 1-14 (doi: 10.1080/15387216.2020.1778499).

Attardo, Salvatore \& Hempelmann, Christian F. \& Di Maio, Sara 2002. Script oppositions and logical mechanisms: Modeling incongruities and their resolutions. Humor International Journal of Humor Research 15 (1), lk 3-46 (doi: 10.1515/humr.2002.004).

Blank, Trevor J. (toim) 2009. Folklore and the Internet: Vernacular Expression in a Digital World. Logan: Utah State University Press.

Blank, Trevor J. (toim) 2012. Folk Culture in the Digital Age: The Emergent Dynamics of Human Interaction. Boulder, CO: University Press of Colorado.

Bobrlife 2020 = Babitš, Veronika. Obiazatel'nyi masochnyi rezhim vveden v Bobruiske. Bobrlife 19. juuni (http://www.bobrlife.by/news/obyazatelnyj-masochnyj-rezhim-vvedenv-bobrujske - 16. veebruar 2021).

Bronner, Simon 2009. Digitizing and Virtualizing folklore. Blank, Trevor J. (toim). Folklore and the Internet: Vernacular Expression in a Digital World. Logan: Utah State University Press, lk 21-66. 
Bronner, Simon 2019. The Practice of Folklore: Essays toward a Theory of Tradition. Jackson, MS: University Press of Mississippi.

Davies, Christie 1990. Ethnic Humour around the World: A Comparative Analysis. Bloomington, IN: Indiana University Press.

Davies, Christie 1998. Jokes and Their Relations to the Society. Berlin: Mouton de Gruyter.

Davies, Christie 2011. Jokes and Targets. Bloomington: Indiana University Press.

Dégh, Linda 1994. American folklore and the mass media. Bloomington \& Indianapolis: Indiana University Press.

Dundes, Alan \& Pagter, Carl R. 1991. Never try to teach a pig to sing: Still more urban folklore from the paperwork empire. Detroit: Wayne State University Press.

Dušakova, Irina 2017. Ot newslore k news, ot news k newslore: istoriia odnogo mema. Shagi/Steps 3 (2), lk 63-76 (http://shagi.ranepa.ru/en/steps/issues/v3n2 - 16. veebruar 2021).

finance.tut.by 2020 = Pochti tret' nanimatelei pereveli sotrudnikov na "udalenku' iz-za koronavirusa. Nekotorye sokratili shtat. Opros 28. märts. finance.tut.by (https://finance. tut.by/news678251.html - 16. veebruar 2021).

Frank, Russell 2004. When the going gets tough, the tough go photoshopping: September 11 and the newslore of vengeance and victimization. New Media \& Society 6 (5), lk 633-658 (doi: 10.1177/146144804047084).

Frank, Russell 2011. Newslore: Contemporary folklore on the Internet. Jackson: University Press of Mississippi.

Girsh, Artem 2020. V Rossii za sutki vyiavili 440 bol'nykh koronavirusom. Vedomosti 1. aprill (https://www.vedomosti.ru/society/articles/2020/04/01/826767-v-rossii-za-sutkiviyavleno-bolnih-koronavirusom - 16. veebruar 2021).

Hentschel, Gerd \& Kittel, Bernhard 2011. Iazykovaia situatsiia v Belarusi: Mneniia belorusov o rasprostranennosti iazykov v strane. Sotsiologiya: nauchno-teoreticheskiy zhurnal 4, lk 62-78.

Ivaniuk, Iryna \& Ovcharuk, Oksana 2020. The response of Ukrainian teachers to COVID-19: challenges and needs in the use of digital tools for distance learning. Information Technologies and Learning Tools 77 (3), lk 282-291 (doi: 10.33407/itlt.v77i3.3952).

Jegelevicius, Linas 2020. Belarus and coronavirus: Lukashenko's business-as-usual approach is 'mind-blowing negligence'. Euronews 21. aprill (https://www.euronews. com/2020/04/21/belarus-and-coronavirus-lukashenko-s-business-as-usual-approachis-mind-blowing-negligence - 16. veebruar 2021).

Kalmre, Eda 2017. Introduction: The Social and Political Dynamic of Conspiracy Theories, Rumours, Fake News, and Belief Narratives. Folklore: Electronic Journal of Folklore 69, lk 7-14 (doi: 10.7592/FEJF2017.69.introduction).

Kaplan, Merrill 2013. Curation and Tradition on Web 2.0. Blank, Trevor J. \& Howard, Robert Glenn (toim). Tradition in the twenty-first century: Locating the role of the past in the present. Boulder: University Press of Colorado, lk 123-148. 
Khurshudyan, Isabelle 2020. Coronavirus is spreading rapidly in Belarus, but its leader still denies there is a problem. The Washington Post 2. mai (https://www.washingtonpost. com/world/europe/coronavirus-is-spreading-rapidly-in-belarus-but-its-leader-stilldenies-theres-a-problem/2020/05/01/a2532ba0-8964-11ea-80df-d24b35a568ae_story. html - 16. veebruar 2021).

Kramer, Andrew E. 2020. 'There Are No Viruses Here': Leader of Belarus Scoffs at Lockdowns. The New York Times 25. aprill (https://www.nytimes.com/2020/04/25/world/ europe/belarus-lukashenko-coronavirus.html - 16. veebruar 2021).

Melnichuk, Tatsiana 2020. Coronavirus: Belarus WW2 parade defies pandemic and upstages Putin. BBC News Russian 9. mai (https://www.bbc.com/news/worldeurope-52574749 - 16. veebruar 2021).

Mieder, Wolfgang 2008. "Proverbs speak louder than words": folk wisdom in art, culture, folklore, history, literature and mass media. New York \& Washington: Peter Lang.

Minski linna täitevkomitee 2020 = Plan dopolnitel'nykh meropriiatii po profilaktike i snizheniiu rasprostraneniia ostrykh respiratornykh infektsii, $\mathrm{v}$ tom chisle vyzvannykh COVID-19, v g. Minske. Minskii gorodskoi ispolnitel'nyi komitet 7. aprill (https://minsk. gov.by/ru/normdoc/4328/1069_plan.shtml - 17. veebruar 2021).

Minzdrav 2020a = V Belarusi zaregistrirovan pervyy zavoznoy sluchay koronavirusa. Ministerstvo Zdravookhraneniia Respubliki Belarus'. Sobytiia. 28. veebruar (http:// minzdrav.gov.by/ru/sobytiya/v-belarusi-zaregistrirovan-zavoznoy-sluchay-koronavirusa. - 17. veebruar 2021).

Minzdrav 2020b = Rekomendatsii po sotsial'nomu distantsirovaniiuv periodregistratsii sluchaev infektsii COVID-19 (koronavirusnoi infektsii). Ministerstvo Zdravookhraneniia Respubliki Belarus' 23. märts (http://minzdrav.gov.by/upload/dadvfiles/letter/Памятка по социальному дистанцированию.pdf - 17. veebruar 2021).

Morris, Ray 1993. Visual Rhetoric in Political Cartoons: A Structuralist Approach. Metaphor and Symbolic Activity 8 (3), lk 195-210 (doi: 10.1207/s15327868ms0803_5).

NSK 2020 = Obshchaia chislennost' naseleniia, chislennost' naseleniia po vozrastu i polu, sostoianiiu v brake, urovniu obrazovaniia, natsional'nostiam, iazyku, istochnikam sredstv $\mathrm{k}$ sushchestvovaniiu po Respublike Belarus'. Natsional'nyy statisticheskiy komitet respubliki Belarus' (https://www.belstat.gov.by/upload/ iblock/471/471b4693ab545e3c40d206338ff4ec9e.pdf - 17. veebruar 2021).

Office life 2020 = Kak menialos' mnenie Lukashenko o koronaviruse s rostom chisla zabolevshikh. Taimlain. Office Life 27. aprill (https://officelife.media/article/people/16483taimline-lukashenko/ - 16. veebruar 2021).

OTV 2020a = Aleksandr Lukashenko: Khokkei - luchshee antivirusnoe lekarstvo! Obshchenatsional'noye televideniye 28. märts (https://ont.by/news/aleksandr-lukashenkohokkej-luchshee-antivirusnoe-lekarstvo - 17. veebruar 2021).

OTV 2020b = Lukashenko ob epidsituatsii: obstanovka uluchshaetsia, no rasslabliat'sia nel'zia. Obshchenatsional'noye televideniye 21. mai (https://ont.by/news/lukashenko-obepidsituacii-obstanovka-uluchshaetsya-no-rasslablyatsya-nelzya - 17. veebruar 2021). 
Oring, Elliott 2003. Engaging Humor. Champaign: University of Illinois Press.

Oring, Elliott 2016. Joking Asides: The Theory, Analysis, and Aesthetics of Humor. Logan: Utah State University Press.

Osipov, Aleksandr 2020. Rasporiazheniye o vvedenii dopolnitel'nykh mer. Mogilevskii oblastnoi ispolnitel'nyi komitet 29. mai (http://www.kirovsk.by/wp-content/ uploads/2020/06/распоряжение.pdf - 17. veebruar 2021).

Peck, Andrew \& Blank, Trevor J. 2020. Folklore and Social Media. Louiseville: University Press of Colorado.

Rodgers, James 2020. In Belarus, President Lukashenko Has Unique Response To Facing Coronavirus. Forbes 4. aprill (https://www.forbes.com/sites/ jamesrodgerseurope/2020/04/04/in-belarus-lukashenko-has-his--own-ways-for-thecountry-to-face-coronavirus/\#64279f3c279d - 17. veebruar 2021).

Shifman, Limor \& Blondheim, Menahem 2010. The medium is the joke: Online humor about and by networked computers. New Media \& Society 12 (8), lk 1348-1367 (doi: 10.1177/1461444810365311).

Starichonok, Vasily 2012. Russkii iazyk v Belarusi: sostoianie, perspektivy. Slovo.ru: Baltiiskii aktsent 2, lk 76-80.

STV 2020a = Aleksandr Lukashenko: Ia chelovek nep'iushchii, no v poslednee vremia $\mathrm{v}$ shutku govoriu, chto vodkoi nado ne tol'ko ruki myt'. Stolichnoe televidenie - STV 16. märts (http://www.ctv.by/aleksandr-lukashenko-ya-chelovek-nepyushchiy-no-vposlednee-vremya-v-shutku-govoryu-chto-vodkoy-nado - 17. veebruar 2021).

STV 2020b = Aleksandr Lukashenko: ia koronavirus etot nazyvaiu ne inache kak psikhozom, i ot etogo nikogda ne otkazhus'. Stolichnoe televidenie - STV 19. märts (http://www.ctv.by/aleksandr-lukashenko-ya-koronavirus-etot-nazyvayut-ne-inachekak-psihozom-i-ot-etogo-nikogda-ne - 17. veebruar 2021).

STV 2020c = Aleksandr Lukashenko: "Psikhoz - eto khuzhe, chem koronavirus. Poetomu ia vas vsegda ottaskivaiu ot etoi bolezni”. Stolichnoe televidenie - STV 28. märts (http:// www.ctv.by/aleksandr-lukashenko-psihoz-eto-huzhe-chem-koronavirus-poetomu-ya-vasvsegda-ottaskivayu-ot-etoy - 17. veebruar 2021).

STV 2020d = Aleksandr Lukashenko o pike virusnykh zabolevanii v Belarusi: Moliu Boga, chtoby do Paskhi on ushel vniz. Stolichnoe televidenie - STV 31. märts (http:// www.ctv.by/aleksandr-lukashenko-o-pike-virusnyh-zabolevaniy-v-belarusi-molyu-bogachtoby-do-pashi-ushyol-vniz - 17. veebruar 2021).

STV 2020e = Aleksandr Lukashenko: karantin, komendantskii chas i prochee. Slushaite, eto proshche vsego - eto my sdelaem v techenie sutok. No zhrat' chto budem? Stolichnoe televidenie - STV 7. aprill (http://www.ctv.by/aleksandr-lukashenko-karantinkomendantskiy-chas-i-prochee-slushayte-eto-proshche-vsego-eto-my - 17. veebruar 2021).

STV 2020f = Aleksandr Lukashenko: "Opiat' novyi psikhoz - chesnochno-imbirnyi". Stolichnoe televidenie - STV 13. aprill (http://www.ctv.by/aleksandr-lukashenko-opyatnovyy-psihoz-chesnochno-imbirnyy - 17. veebruar 2021). 
Tomashevski, Kirill 2020. COVID-19 and Labour Law: Belarus. Italian Labour Law e-Journal 13 (1S) (doi: 10.6092/issn.1561-8048/10960).

Valgevene Vabariigi president 2020a = Meeting with Head of Belarus President Administration, Chairwoman of Council of Republic, State Secreatry of Security Council, Healthcare Minister. The official Internet Portal of the President of the Republic of Belarus 13. aprill (http://president.gov.by/en/news_en/view/report-of-head-of-belaruspresident-administration-chairwoman-of-council-of-republic-state-secreatry-of-23389/_ 17. veebruar 2021).

Valgevene Vabariigi president 2020b = Vrucheniye gosudarstvennykh nagrad. The official Internet Portal of the President of the Republic of Belarus 2. juuli (http://president. gov.by/ru/news_ru/view/vruchenie-gosudarstvennyx-nagrad-23940/).

\title{
Summary
}

\section{Internet folklore in times of global pandemic: COVID-19 in Belarusian online humor}

\author{
Anastasiya Fiadotava \\ Estonian Literary Museum \\ anastasiya.fiadotava@folklore.ee
}

Keywords: COVID-19, global, humor, memes, newslore

During the first months of the COVID-19 pandemic (February-July 2020) I collected 374 textual jokes, humorous images, and image macros related to the coronavirus from Belarusian social media, friends, and family members. Many of the examples in my dataset became local memes, circulating within and beyond the Belarusian mediascape. While the Belarusian government's dismissive response to the pandemic was unique among the Eastern European nations, only 34 of my examples referred specifically to the situation in Belarus. Many more examples addressed such issues as living under a lockdown, compulsory mask wearing, and distant working and learning, even though these measures were not implemented in the country on a mass scale. This incongruity between people's lived experience in Belarus and the content of humorous folklore circulating in the country illustrates the influence of global media coverage on vernacular humorous expressions. These vernacular expressions point to strong connections between the Belarusian mediascape and those of other countries, especially Russia, from where many of the examples originated.

The paper also reflects a broader issue of globalization and digitalization of contemporary folklore, discusses the phenomenon of newslore and illustrates how some of the common characteristics of folklore can be applied to the digital forms of vernacular expression. The paper also looks at the balance between global and local in the online folklore. 
Anastasiya Fiadotava (PhD) on Eesti Kirjandusmuuseumi folkloristika osakonna nooremteadur ja Eesti-uuringute Tippkeskuse liige. Tema huvialad on folkloristika, huumoriuuringud ja perekonna rahvaluule. Tal on Valgevene ajaloo magistrikraad Valgevene Riikliku Ülikoolist ja folkloristika doktorikraad Tartu Ülikoolist. Tema doktoritöö keskendus Valgevene perekonna humoorikale rahvaluulele.

Anastasiya Fiadotava $(\mathrm{PhD})$ is Junior Research Fellow at the Department of Folkloristics of the Estonian Literary Museum, and at the Centre of Excellence in Estonian Studies. Her fields of interest include folkloristics, humour studies, and family lore. She holds an MA in Belarusian history from Belarusian State University, and a PhD from the University of Tartu. Her PhD thesis focuses on humorous family lore in Belarus.

anastasiya.fiadotava@folklore.ee 